\title{
Gain of chromosome 7, as detected by in situ hybridization, strongly correlates with shorter survival in astrocytoma grade 2.
}

Citation for published version (APA):

Wessels, P. H., Twijnstra, A., Kessels, A. G. H., Krijne-Kubat, B., Theunissen, P. H., Ummelen, M. I., Ramaekers, F. C. S., \& Hopman, A. H. N. (2002). Gain of chromosome 7, as detected by in situ hybridization, strongly correlates with shorter survival in astrocytoma grade 2. Genes Chromosomes \& Cancer, 33, 279-284. https://doi.org/10.1002/gcc.10029

Document status and date:

Published: 01/01/2002

DOI:

10.1002/gcc.10029

Document Version:

Publisher's PDF, also known as Version of record

\section{Please check the document version of this publication:}

- A submitted manuscript is the version of the article upon submission and before peer-review. There can be important differences between the submitted version and the official published version of record.

People interested in the research are advised to contact the author for the final version of the publication, or visit the DOI to the publisher's website.

- The final author version and the galley proof are versions of the publication after peer review.

- The final published version features the final layout of the paper including the volume, issue and page numbers.

Link to publication

\footnotetext{
General rights rights.

- You may freely distribute the URL identifying the publication in the public portal. please follow below link for the End User Agreement:

www.umlib.nl/taverne-license

Take down policy

If you believe that this document breaches copyright please contact us at:

repository@maastrichtuniversity.nl

providing details and we will investigate your claim.
}

Copyright and moral rights for the publications made accessible in the public portal are retained by the authors and/or other copyright owners and it is a condition of accessing publications that users recognise and abide by the legal requirements associated with these

- Users may download and print one copy of any publication from the public portal for the purpose of private study or research.

- You may not further distribute the material or use it for any profit-making activity or commercial gain

If the publication is distributed under the terms of Article $25 \mathrm{fa}$ of the Dutch Copyright Act, indicated by the "Taverne" license above, 


\title{
Gain of Chromosome 7, as Detected by In Situ Hybridization, Strongly Correlates With Shorter Survival in Astrocytoma Grade 2
}

\author{
Peter H. Wessels, ${ }^{1 *}$ Albert Twijnstra, ' Alfons G. H. Kessels, ${ }^{2}$ Bela Krijne-Kubat, ${ }^{3}$ Paul H. Theunissen, \\ Monique I. J. Ummelen, ${ }^{5}$ Frans C. S. Ramaekers, ${ }^{5}$ Anton H. Hopman ${ }^{5}$ \\ 'Department of Neurology, University Hospital Maastricht, Maastricht, Netherlands \\ ${ }^{2}$ Department of Clinical Epidemiology, University Hospital Maastricht, Maastricht, Netherlands \\ ${ }^{3}$ Department of Pathology, University Hospital Maastricht, Maastricht, Netherlands \\ ${ }^{4}$ Department of Pathology, Atrium Medical Center, Heerlen, Netherlands \\ ${ }^{5}$ Department of Molecular Cell Biology, University Maastricht, Netherlands
}

The clinical course of astrocytoma grade 2 (A2) is highly variable and is not reflected by morphological characteristics. Earlier studies using small series of $\mathrm{A} 2$ cases suggest that in situ hybridization (ISH) with chromosome-specific DNA probes allows for frequent detection of aneusomy I, trisomy 7 , and monosomy 10. The role of trisomy 7 in astrocytoma carcinogenesis is disputed, however, because of its presence in non-neoplastic brain tissue, as detected by karyotyping. Our objective was to investigate whether there was a correlation between chromosomal aberrations and survival in a series of 47 cases of A2. All cases were evaluated for numerical aberrations of chromosomes I, 7, and 10 by ISH. Chromosomal aberrations were detected in $68 \%$ of cases of A2. Trisomy/polysomy 7 was seen in 31 cases $(66 \%), 22$ of which (47\%) had a high percentage of this numerical aberration. Only II of these 22 cases also showed aneusomy for I or 10 . No cells or only a few cells with aberrations were detected in non-neoplastic control samples. Using Kaplan-Meier analysis, trisomy/polysomy 7 correlated significantly with shorter survival. Hence, as determined by ISH, trisomy/polysomy 7 is absent in non-neoplastic brain tissue and is frequently detected in A2, correlating with the malignant progression of the disease. ๑ 2002 Wiley-Liss, Inc.

\section{INTRODUCTION}

Genotypic characterization of astrocytoma grade 2 (A2) not only is important in understanding carcinogenesis but also might offer prognostic information. Such prognostic information may help resolve the controversy that exists with regard to the optimal treatment of A2. So far, only a few studies have investigated the correlation between cytogenetic aberrations and the clinical course of A2 (Kraus et al., 1994; Perry et al., 1997; Sallinen et al., 1997). Using classic karyotyping, Kimmel and collegues (1992) showed that patients with astrocytomas with clonal abnormalities had shorter survival times compared with patients with astrocytomas without these abnormalities. Their group of cases of A2 was too small for separate analysis, however.

The most frequently reported genetic aberrations in A2 include mutation of TP53, loss of heterozygosity (LOH) of chromosome arm 17p (von Deimling et al., 1992), and trisomy 7 (Rey et al., 1987). A correlation between TP53 mutations and survival of A2 patients seems unlikely (Kraus et al., 1994; Al-Sarraj and Bridges, 1995). Previous studies in small series of A2 cases suggest that in situ hybridization (ISH) and comparative genomic hybridization $(\mathrm{CGH})$ allow for frequent detection of chromosomal aberrations, such as gain of chromosomes 1 and 7, loss of chromosome 10, and hyperdiploidy (Table 1). Only two of these investigators correlated the cytogenetic results with the clinical course of patients with A2 (Perry et al., 1997; Sallinen et al., 1997). Sallinen et al. (1997) suggested the possible prognostic value of CGH in a series of 11 A2 cases. Perry et al. (1997) concluded that deletion of chromosome 10 was of prognostic value when studying the total spectrum of astrocytomas, while trisomy 7 showed no significant correlation with postoperative survival. The role of trisomy 7 in carcinogenesis of astrocytomas is controversial, given the fact that this aberration has been detected in cultured, histologically nonmalignant brain tissues (Heim et al., 1989; Moertel et al., 1993). In contrast, trisomy 7 has not been detected by ISH of normal and gliotic brain tissue (Arnoldus et al., 1992; Dalrymple et al., 1994). The objective

Supported by: Dutch Cancer Society; Nijbakker Morra Foundation.

*Correspondence to: Peter Wessels, M.D., Department of Neurology, University Hospital Maastricht, P.O. Box 5800, 6202 AZ Maastricht, Netherlands. E-mail: PWES@SNEU.AZM.NL

Received 8 June 2001; Accepted 11 September 2001 
TABLE I. Summary of Results in the Literature of In Situ Hybridization (ISH) and Comparative Genomic Hybridization (CGH) Studies in Adult Astrocytoma Grade 2 (A2)*

\begin{tabular}{|c|c|c|c|}
\hline $\begin{array}{l}\text { Method and } \\
\text { chromosomes examined }\end{array}$ & $\begin{array}{l}\text { Number of } \\
\text { cases (A2) }\end{array}$ & $\begin{array}{l}\text { Chromosome } \\
\text { aberrations detected }\end{array}$ & Reference \\
\hline ISH I0, I7 & 11 & $-10,-17,+17$ & Campomenosi et al., 1996 \\
\hline ISH 7, I0, X, Y & 10 & $+7,-10$ & Liu et al., 1997 \\
\hline ISH 7, I0, 3 & 11 & $+7,-10$ & Perry et al., 1997 \\
\hline ISH I, 7, I0, I7, X, Y, Ip36 & 4 & +7 , Aneuploidy & Rosso et al., 1997 \\
\hline ISH 7, 10 & 3 & Tetrasomy 7 and 10 & Steilen-Gimbel et al., 1996 \\
\hline ISH I, 2, 7, Ip36 & 9 & $+I,-I p 36,+7$ & Wernicke et al., 1997 \\
\hline $\mathrm{CGH}$ & 9 & $\begin{array}{l}+8 q \\
-1 p,+ \text { Ipter, }+7 q,+8 q\end{array}$ & Nishizaki et al., I998 \\
\hline $\mathrm{CGH}$ & II & -10 & Sallinen et al., 1997 \\
\hline $\mathrm{CGH}$ & 10 & $\begin{array}{l}+7,+7 q,+8 q \\
-5 p,+8 q,+12 p,+19 p\end{array}$ & Schrock et al., 1994 \\
\hline $\mathrm{CGH}$ & 10 & $-X_{p}$ & Weber et al., 1996 \\
\hline
\end{tabular}

*For $\mathrm{CGH}$, the most frequent aberrations are listed.

in this study was to reinvestigate the prognostic value of chromosome 7 aberration in A2. The ISH technique was applied to routinely processed, paraffin-embedded biopsy and resection samples, allowing for precise correlation of the genetic constitution of cells with their histologic features.

\section{MATERIALS AND METHODS}

\section{Material from Patients}

Forty-seven biopsy and resection samples diagnosed as supratentorial low-grade diffuse astrocytoma or A2 were collected from the files of the Departments of Pathology of the University Hospitals of Maastricht and Groningen and the Atrium Hospital in Heerlen. Astrocytomas diagnosed in patients under the age of 18 years were excluded. The samples were revised according to the World Health Organization (WHO) classification (Kleihues et al., 1993). Overall survival was assessed from the patients' records. As controls, 10 samples with nonneoplastic reactive gliosis were examined (Wessels et al., 2001). These samples were derived at postmortem examination from patients who died from non-neoplastic neurological causes, that is, brain infarction $(n=5)$, hemorrhagic infarction $(n=1)$, traumatic hemorrhage $(n=2)$, and hypoxic encephalopathy $(n=2)$.

\section{ISH Protocol}

The most representative paraffin blocks were selected from the 47 A2 cases. Five-micron-thick sections were cut and pretreated according to a recently optimized protocol (Hopman and Ramaekers, 1998). After deparaffinization in xylol and dehydration in an ethanol series, the tissues were pretreated in $85 \%$ formic acid containing $0.3 \%$ $\mathrm{H}_{2} \mathrm{O}_{2}$ for $20 \mathrm{~min}$ at room temperature. After dehydration in an acidified ethanol series, the specimens were incubated at $80^{\circ} \mathrm{C}$ in $1 \mathrm{M}$ sodium thiocyanate. Proteolytic digestion was performed in 4 $\mathrm{mg} / \mathrm{mL}$ pepsin (from porcine stomach; 2,500-3,500 U per $100 \mathrm{mg}$ protein; Sigma, St. Louis, MO) for 10 min at $37^{\circ} \mathrm{C}$ in $0.02 \mathrm{M} \mathrm{HCl}$. After dehydration in an acidified ethanol series, the tissues were fixed in $1 \%$ formaldehyde in phosphate-buffered saline (PBS) for $15 \mathrm{~min}$, followed by five subsequent washing steps in PBS and double-distilled water.

ISH was performed as described earlier (Hopman and Ramaekers, 1998). The DNA probes used were specific for the heterochromatin (sub-)centromere region of chromosome 1 (1q12, pUC 1.77; Cooke and Hindley, 1979), the alphoid region of chromosome 7 (p7t1; Waye et al., 1987), and the centromere region of chromosome 10 (D10Z1; Devilee et al., 1988). After denaturation at $80^{\circ} \mathrm{C}$ for 5 min, hybridization was performed overnight at $37^{\circ} \mathrm{C}$ under a coverslip in a mixture containing $2 \times$ standard saline citrate (SSC), $60 \%$ formamide, $10 \%$ dextran sulfate, and $0.2 \mathrm{mg} / \mathrm{mL}$ herring sperm DNA. Post-hybridization washes included two washes in $2 \times \mathrm{SSC} / 0.05 \% / \mathrm{Tween}$ at $40^{\circ} \mathrm{C}$ for 5 min, followed by two washes in $0.1 \times \mathrm{SSC}$ at $60^{\circ} \mathrm{C}$ for $5 \mathrm{~min}$. The biotin-labeled DNA probes were detected by an immunoperoxidase precipitation reaction. The slides were incubated for $30 \mathrm{~min}$ at room temperature with mouse-antibiotin monoclonal antibody, followed by biotinylated horse-antimouse immunoglobulin $G$ and then with avidinbiotin-peroxidase complex (all reagents from Vector Laboratories, Burlingame, CA). Finally, dia- 
minobenzidine (Sigma) in PBS containing 0.03\% $\mathrm{H}_{2} \mathrm{O}_{2}$ was applied for visualization of the peroxidase activity. To improve identification of overlapping nuclei, we used a novel method that includes fluorescent DNA counterstaining with 4'6-diamino-2phenylindole (DAPI; Sigma) and bright-field ISH. Microscopy was performed using a Leica-DMBRE microscope (Leica Mikroskopie und Systeme GmbH, Wetzlar, Germany) equipped with a filter set for DAPI.

\section{Evaluation of ISH}

The number of ISH signals per nucleus was counted in at least 200 nonoverlapping nuclei, following the criteria proposed by Hopman et al. (1992). Monosomy was defined as $>25 \%$ of nuclei with no signal or one signal per nucleus. Trisomy/ polysomy is defined as $\geq 5 \%$ of nuclei containing three or more signals. In accordance with other studies, $20 \%$ of aberrant nuclei was used as the cutoff for a high-frequency aberration (Campomenosi et al., 1996; Perry et al., 1997). The ISH results were categorized as "normal" $(<5 \%$ aberrant nuclei), "low-aberrant" (5-20\% aberrant nuclei), and "high-aberrant" ( $>20 \%$ aberrant nuclei). The prognostic value of these numerical chromosome aberrations was analyzed using log-rank tests on Kaplan-Meier curves.

\section{RESULTS}

Histologic revision of the 47 cases of A2 showed $42(89 \%)$ cases of fibrillary astrocytoma, three $(7 \%)$ cases of gemistocytic astrocytoma, and two (4\%) cases of oligo-astrocytomas (all WHO grade 2). Forty-five cases were primary tumors, and two were recurrences from A2. No patients had been previously subjected to radiotherapy. Twenty-nine (62\%) patients had undergone stereotactic biopsy, and in $18(38 \%)$ patients the samples had been obtained by surgical resection. The follow-up period varied from 24 to 200 months. The median survival interval was 90 months (95\% CI: $72-108$ months).

Using probes for chromosomes 1,7 , and 10, the samples with reactive gliosis showed no cells or only sporadic cells with three ISH signals, and they were all classified as normal for all three chromosomes (Fig. 1a). Of the cases of A2, 31 (66\%) showed aberrations for one or more of the chromosomes investigated (Table 2). The frequency of cells exhibiting numerical chromosomal aberrations exceeded $5 \%$ in $51 \%$ of the cases for chromosome 1 , in $66 \%$ of the cases for chromosome 7 (Fig. 1b), and in $53 \%$ of the cases for chromosome 10 . High-
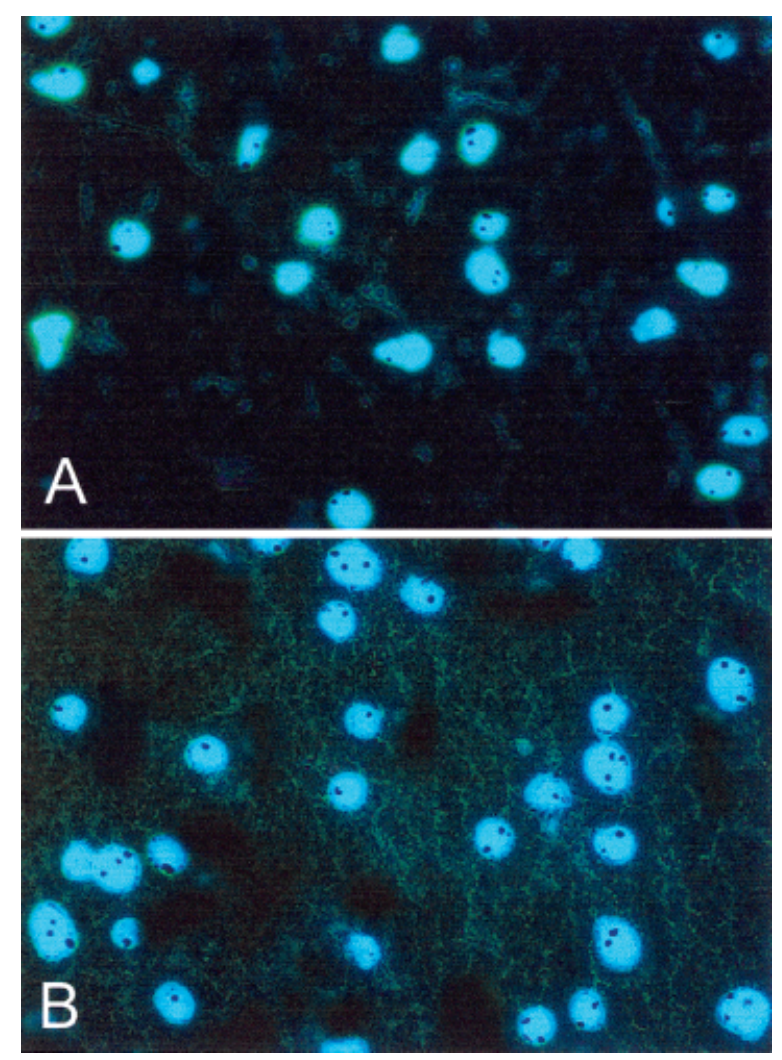

Figure I. Bright-field microscopy of ISH for chromosome 7 combined with DAPI counterstaining of nuclei. A: A sample of reactive gliosis with no aberrations for chromosome 7. B: A2 showing many nuclei with three signals for chromosome 7. Magnification for both A and $\mathrm{B} \times 800$.

TABLE 2. Summary of In Situ Hybridization Results in 47 Cases of Astrocytoma Grade 2*

\begin{tabular}{lcrl}
\hline Category & $\begin{array}{c}\text { Chromo- } \\
\text { some I }\end{array}$ & $\begin{array}{c}\text { Chromo- } \\
\text { some 7 }\end{array}$ & $\begin{array}{c}\text { Chromo- } \\
\text { some 10 }\end{array}$ \\
\hline Normal $^{\mathrm{a}}$ & $23(49 \%)$ & $16(34 \%)$ & $22(47 \%)$ \\
Low-aberrant $^{\mathrm{b}}$ & $21(45 \%)$ & $9(19 \%)$ & $15(32 \%)$ \\
High-aberrant $^{\mathrm{c}}$ & $3(6 \%)$ & $22(47 \%)$ & $10(21 \%)$ \\
\hline
\end{tabular}

${ }^{\text {a Normal }}=<5 \%$ of cells per case with chromosomal aberrations.

bow-aberrant $=5-20 \%$ of cells per case with chromosomal aberrations.

'High-aberrant $=>20 \%$ of cells per case with chromosomal aberrations.

*The number (percentage) of cases with numerical chromosomal aberrations belonging to the indicated categories is presented.

frequency aberrations with increased copy numbers most often were detected for chromosome 7 . In $47 \%$ of the samples, the frequency of cells with aberrations exceeded 20\%. A much more limited number of cases falling into the "high-aberrant" category were detected with probes for chromosomes 1 and 10 (Table 2). The most frequently detected numerical aberrations of chromosome 7 consisted of trisomies (28 cases), but a few cases 


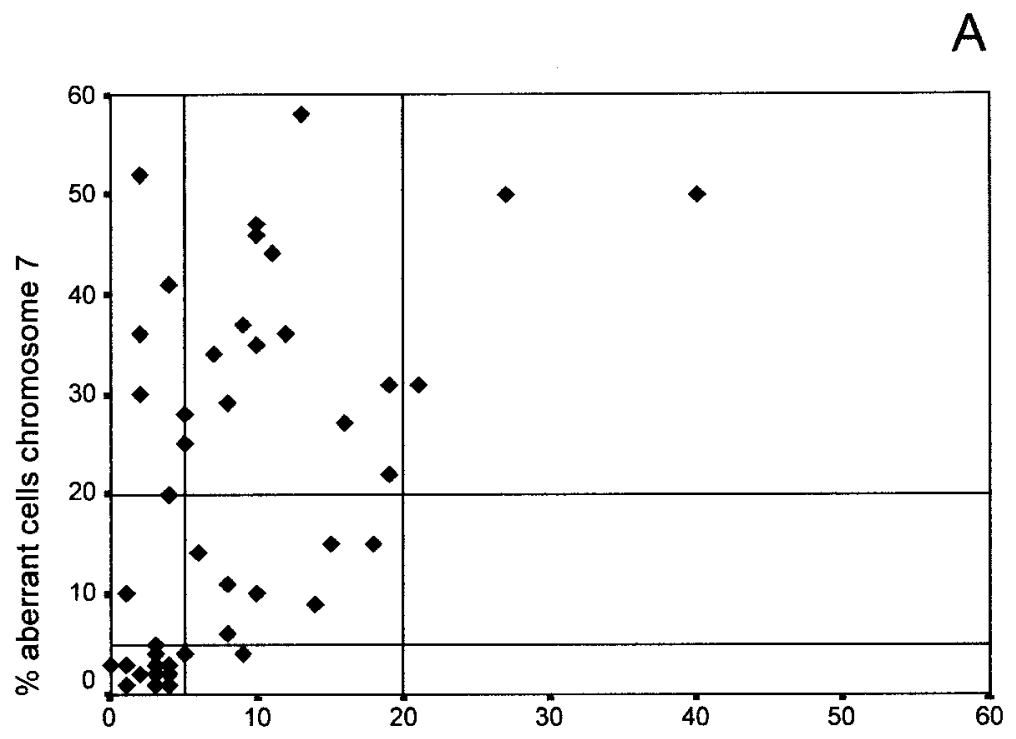

\% aberrant cells chromosome 1

B

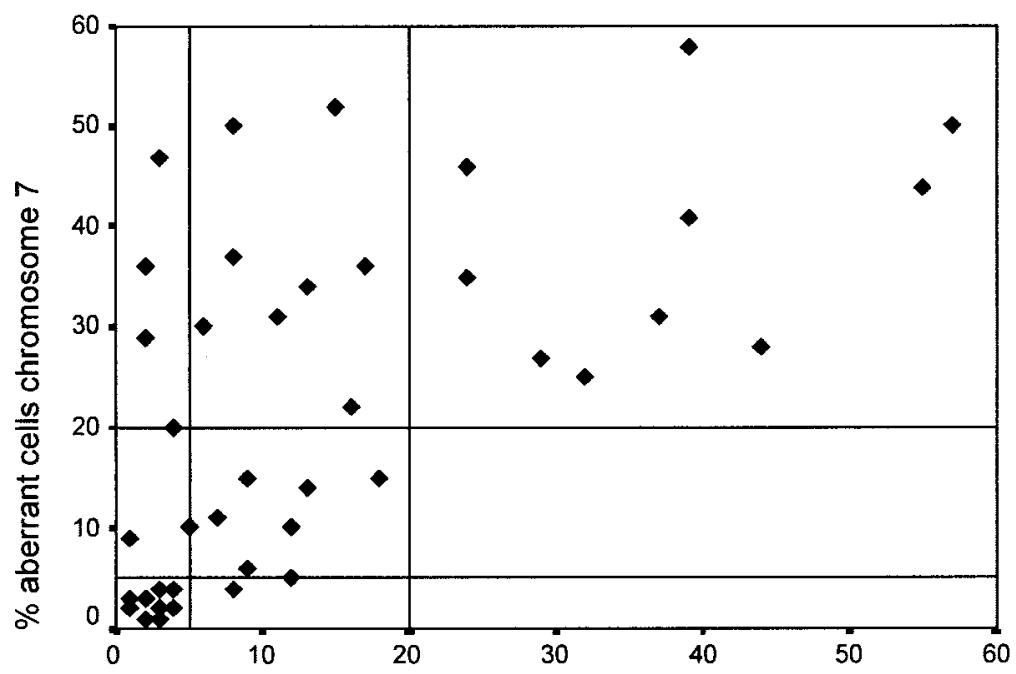

$\%$ aberrant cells chromosome 10

Figure 2. Scattergram showing the percentages of aberrant nuclei for chromosome 7 versus chromosome 7 (A) and for chromosome 7 versus chromosome 10 (B) for each of the individual cases of $A$ $2(n=47)$.

showed higher copy numbers (three cases). All numerical aberrations of chromosomes 1 or 10 were increases in copy numbers, except for two cases with monosomy 10.

In Figure 2, the individual cases and the correlation between the percentages of aberrant nuclei for chromosomes 7 and 1 (Fig. 2a) and chromosomes 7 and 10 (Fig. 2b) have been depicted. As is shown, virtually all cases with aberrations of chromosomes 1 or 10 also exhibited high frequencies of cells with aberrations of chromosome 7. The reverse, that is, cases with aberrations of chromosome 7 also showing chromosome 1 and 10 deviations, holds true only for a limited number of cases. The results of the Kaplan-Meier analyses are shown in Figure 3. Trisomy/polysomy 7, according to the different categories, correlated with shorter survival (log-rank test: $P=0.028$ ). High-frequency aberrations of chromosome 7 ( $>20 \%$ of trisomicl polysomic cells as cutoff; high-aberrant group) cor- 
Figure 3. Survival of patients with $\mathrm{A} 2$ classified on the basis of aberrations of chromosome 7 . High percentages $(>20 \%)$ of aberrant nuclei for chromosome 7 correlate most strongly with shorter survival times (log-rank: $P=0.028)$.

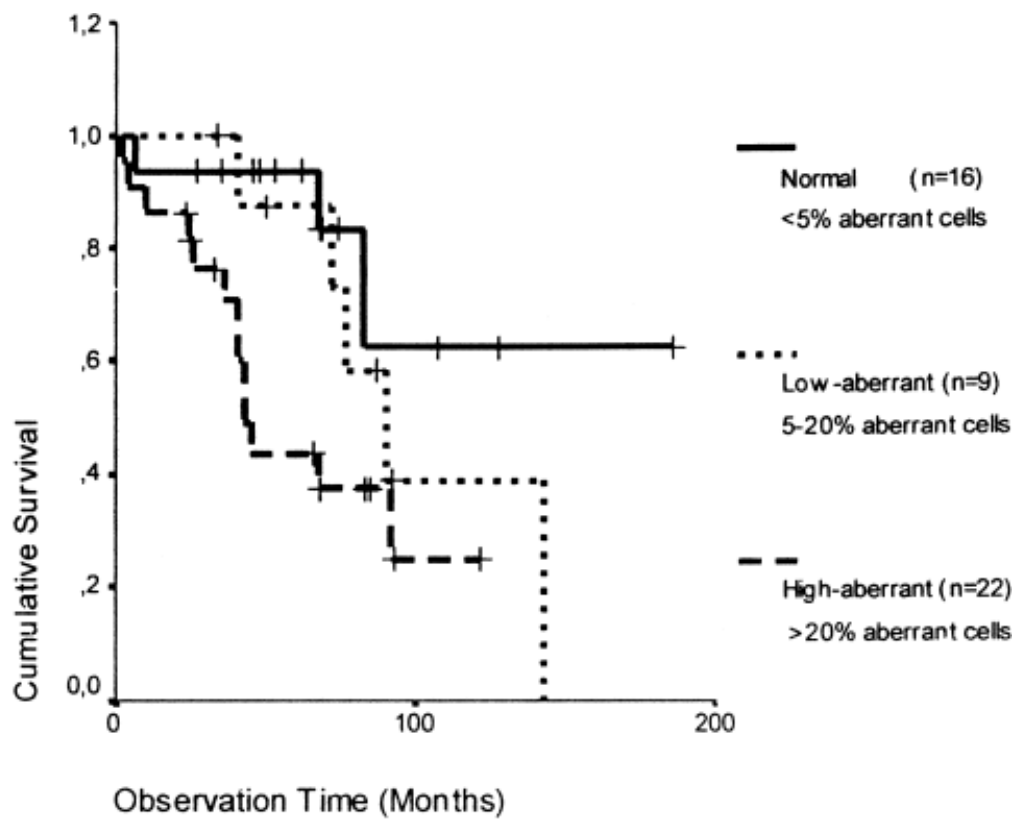

related strongly with shorter survival times, compared with A2 with disomy or a low frequency of aberrations for chromosome 7 (normal and lowaberrant group taken together; log-rank test: $P=$ 0.008; not shown in Fig. 3). The two tumors with monosomy 10 were associated with extremely short survival intervals, that is, 10 and 24 months.

\section{DISCUSSION}

The present study shows that numerical aberrations of chromosome 7 occur frequently in A2 and that their detection by ISH is of prognostic value. The absence or extremely low frequency of numerical chromosome 7 aberrations in the control samples with non-neoplastic reactive gliosis is in accordance with the results of earlier ISH studies in non-neoplastic brain tissue (Arnoldus et al., 1991; Dalrymple et al., 1994). This may suggest that trisomy 7, as detected by classic banding analysis in normal (Heim et al., 1989) and gliotic (Moertel et al., 1993) brain tissue, most probably is due to culturing artifacts. Another possible explanation is that the normal brain tissues in the study of Heim et al. (1989) contained malignant cells, because seven of their 11 patients were reported to have malignant brain tumors. Owing to limitations of the ISH technique, however, we cannot rule out the presence of small clones of cells with trisomy 7 in our gliotic samples.

Our ISH findings in A2 corroborate results of previous, smaller series (Table 1). Perry et al. (1997) described trisomy 7 in half of the A2 cases they examined. In a double-labeled ISH experiment, Steilen-Gimbel et al. (1996) showed gains of both chromosomes 7 and 10. CGH studies also suggest that gain or amplification of chromosome 7 and $\operatorname{arm} 8 \mathrm{q}$, in particular, is typical of A2 (Table 1). In this study we showed that high-frequency trisomy/polysomy of chromosome 7 is strongly correlated with shorter survival times, suggesting clonal expansion of this cell population during the malignant progression of A2.

Polysomy, in particular trisomy, of chromosome 7 not only is detected frequently in A2 but also is seen in other preneoplastic and neoplastic lesions. Trisomy 7 was shown to correlate with poor prognosis in prostate carcinoma (Bandyk et al., 1994). Furthermore, this aberration is present in the stemcell compartment of colon carcinoma and has been suggested to be involved in the transition of colon adenoma to carcinoma (Herbergs et al., 1996). Thyroid hyperplasia with trisomy 7 is thought to progress more often to adenoma and carcinoma (Belge, 1994).

These studies and our present findings strongly support the involvement of trisomy/polysomy 7 in carcinogenesis and tumor progression. We found no strong indications that trisomy/polysomy 7 is associated with reactive gliosis and therefore cannot support the suggestion that this represents a preneoplastic process (Moertel et al., 1993). Furthermore, the presence of trisomy/polysomy $7 \mathrm{did}$ not correlate with the age of the patients in the series of A2 cases described here (unpublished 
results), as was suggested for several other types of solid tumors by Broberg et al. (2001). We conclude that A2 frequently shows a considerable number of tumor cells with trisomy/polysomy 7 . The detection of this numerical chromosomal aberration by ISH may thus be of prognostic value in this type of brain tumor.

\section{ACKNOWLEDGMENTS}

The authors thank Prof. J.J.A. Mooij and Dr. E.W. Hoving, Department of Neurosurgery, University Hospital Groningen, and Dr. M. Nap, Department of Pathology, Atrium Hospital Heerlen, for contributing clinical data and tissue material.

\section{REFERENCES}

Al-Sarraj S, Bridges LR. 1995. P53 immunoreactivity in astrocytomas and its relationship to survival. Br J Neurosurg 9:143-149.

Arnoldus EP, Noordermeer IA, Peters AC, Raap AK, Van der Ploeg M. 1991. Interphase cytogenetics reveals somatic pairing of chromosome 17 centromeres in normal human brain tissue, but no trisomy 7 or sex-chromosome loss. Cytogenet Cell Genet 56:214216.

Arnoldus EP, Wolters LB, Voormolen JH, van Duinen SG, Raap AK, van der Ploeg M, Peters AC. 1992. Interphase cytogenetics: new tool for the study of genetic changes in brain tumors. J Neurosurg 76:997-1003.

Bandyk MG, Zhao L, Troncoso P, Pisters LL, Palmer JL, von Eschenbach AC, Chung LW, Liang JC. 1994. Trisomy 7: a potential cytogenetic marker of human prostate cancer progression. Genes Chromosomes Cancer 9:19-27.

Belge G, Thode B, Rippe V, Bartnitzke S, Bullerdiek J. 1994. A characteristic sequence of trisomies starting with trisomy 7 in benign thyroid tumors. Hum Genet 94:198-202.

Broberg K, Toksvig-Larsen S, Lindstrand A, Mertens F. 2001. Trisomy 7 accumulates with age in solid tumors and non-neoplastic synovia. Genes Chromosomes Cancer 30:310-315.

Campomenosi P, Ottaggio L, Moro F, Urbini S, Bogliolo M, Zunino A, Camoriano A, Inga A, Gentile SL, Pellegata NS, Bonassi S, Bruzzone E, Iannone R, Pisani R, Menichini P, Ranzani GN, Bonatti S, Abbondandolo A, Fronza G. 1996. Study on aneuploidy and p53 mutations in astrocytomas. Cancer Genet Cytogenet 88:95-102.

Cooke HJ, Hindley J. 1979. Cloning of human satellite III DNA: different components are on different chromosomes. Nucleic Acid Res 6:3177-3197.

Dalrymple SJ, Herath JF, Borell TJ, Moertel CA, Jenkins RB. 1994. Correlation of cytogenetic and fluorescence in situ hybridization (FISH) studies in normal and gliotic brain. J Neuropathol Exp Neurol 53:448-456.

Devilee P, Kievits T, Waye JS, Pearson PL, Willard HF. 1988. Chromosome-specific alpha satellite DNA: isolation of a polymorphic alphoid repeat from human chromosome 10. Genomics 3:1-7.

Heim S, Mandahl N, Jin Y, Stromblad S, Lindstrom E, Salford LG, Mitelman F. 1989. Trisomy 7 and sex chromosome loss in human brain tissue. Cytogenet Cell Genet 52:136-138.

Herbergs J, Arends JW, Bongers EM, Ramaekers FC, Hopman AH. 1996. Clonal origin of trisomy for chromosome 7 in the epithelial compartment of colon neoplasia. Genes Chromosomes Cancer 16:106-112.

Hopman AHN, Ramaekers FCS. 1998. Processing and staining of cell and tissue material for interphase cytogenetics. In: Robinson JP, editor. Current protocols in cytometry. New York: John Wiley \& Sons, Inc.
Hopman AHN, Poddighe P, Moesker O, Ramaekers FCS. 1992. Interphase cytogenetics: an approach to the detection of genetic aberrations in tumours. In: Herrington CS, McGee JOD, editors. Diagnostic molecular pathology. Oxford: IRL Press. p 141-161.

Kimmel DW, O'Fallon JR, Scheithauer BW, Kelly PJ, Dewald GW, Jenkins RB. 1992. Prognostic value of cytogenetic analysis in human cerebral astrocytomas. Ann Neurol 31:534-542.

Kleihues P, Burger PC, Scheithauer BW. 1993. Histological typing of tumors of the central nervous system, 2nd ed. Geneva: World Health Organization.

Kraus JA, Bolln C, Wolf HK, Neumann J, Kindermann D, Fimmers R, Forster F, Baumann A, Schlegel U. 1994. TP53 alterations and clinical outcome in low grade astrocytomas. Genes Chromosom Cancer 10:143-149.

Liu N, Numa Y, Kasai H, Tsuchida T, Kawamoto K. 1997. Analysis of sex chromosomal numerical aberrations in human astrocytomas by FISH. Int J Oncol 10:497-502.

Moertel CA, Dahl RJ, Stalboerger PG, Kimmel DW, Scheithauer BW, Jenkins RB. 1993. Gliosis specimens contain clonal cytogenetic abnormalities. Cancer Genet Cytogenet 67:21-27.

Nishizaki T, Ozaki S, Harada K, Ito H, Arai H, Beppu T, Sasaki K. 1998. Investigation of genetic alterations associated with the grade of astrocytic tumor by comparative genomic hybridization. Genes Chromosomes Cancer 21:340-346.

Perry A, Tonk V, McIntire DD, White CL. 1997. Interphase cytogenetic (in situ hybridization) analysis of astrocytomas using archival, formalin-fixed, paraffin-embedded tissue and nonfluorescent light microscopy. Am J Clin Pathol 108:166-174.

Rey JA, Bello MJ, de Campos JM, Kusak ME, Moreno S. 1987. Chromosomal composition of a series of 22 human low-grade gliomas. Cancer Genet Cytogenet 29:223-237.

Rosso SM, van Dekken H, Krishnadath KK, Alers JC, Kros JM. 1997. Detection of chromosomal changes by interphase cytogenetics in biopsies of recurrent astrocytomas and oligodendrogliomas. J Neuropathol Exp Neurol 56:1125-1131.

Sallinen SL, Sallinen P, Haapasalo H, Kononen J, Karhu R, Helen P, Isola J. 1997. Accumulation of genetic changes is associated with poor prognosis in grade II astrocytomas. Am J Pathol 151:17991807.

Schrock E, Thiel G, Lozanova T, du Manoir S, Meffert MC, Jauch A, Speicher MR, Nurnberg P, Vogel S, Janisch W, Donis-Keller H, Ried T, Witkowski R, Cremer T. 1994. Comparative genomic hybridization of human malignant gliomas reveals multiple amplification sites and nonrandom chromosomal gains and losses. Am J Pathol 144:1203-1218.

Steilen-Gimbel H, Henn W, Kolles H, Moringlane JR, Feiden W, Steudel WI, Zang KD. 1996. Early proliferation enhancement by monosomy 10 and intratumor heterogeneity in malignant human gliomas as revealed by smear preparations from biopsies. Genes Chromosom Cancer 16:180-184.

von Deimling A, Eibl RH, Ohgaki H, Louis DN, von Ammon K, Petersen I, Kleihues P, Chung RY, Wiestler OD, Seizinger BR. 1992. P53 mutations are associated with 17 p allelic loss in grade II and grade III astrocytoma. Cancer Res 52:2987-2990.

Waye JS, England SB, Willard HF. 1987. Genomic organisation of alpha satellite DNA on human chromosome 7: evidence for two distinct alphoid domains on a single chromosome. Mol Cell Biol 7:349-356.

Weber RG, Sabel M, Reifenberger J, Sommer C, Oberstrass J, Reifenberger G, Kiessling M, Cremer T. 1996. Characterization of genomic alterations associated with glioma progression by comparative genomic hybridization. Oncogene 13:983-994.

Wernicke C, Thiel G, Lozanova T, Vogel S, Witkowski R. 1997. Numerical aberrations of chromosomes 1,2, and 7 in astrocytomas studied by interphase cytogenetics. Genes Chromosomes Cancer 19:6-13.

Wessels PH, Hopman AHN, Ummelen MIJ, Krijne-Kubat B, Ramaekers FCS, Twijnstra A. 2001. Differentiation between reactive gliosis and diffuse astrocytoma by in situ hybridization. Neurology 56:1224-1227. 